\title{
Heterosis and Combining Ability Studies in Sorghum (Sorghum bicolor (L.) Moench) Over the Environments
}

\author{
R.R. Jadhav ${ }^{1 *}$ and D.T. Deshmukh ${ }^{2}$ \\ ${ }^{1}$ Department of Agricultural Botany, PGI, Dr. PDKV, Akola-444104, Maharashtra, India \\ ${ }^{2}$ Sorghum Breeder, Sorghum Research Unit, Dr. PDKV, Akola-444104, Maharashtra, India \\ *Corresponding author
}

\author{
A B S T R A C T
}

\begin{tabular}{|l|}
\hline Ke y w o r d s \\
Combining ability, \\
Gene action, \\
Heterosis, Line x \\
Tester, Sorghum. \\
\hline Article Info \\
\hline $\begin{array}{l}\text { Accepted: } \\
\text { 26 September } 2017 \\
\text { Available Online: } \\
\text { 10 October } 2017\end{array}$ \\
\hline
\end{tabular}

An investigation was carried out across four environments to assess magnitude of heterosis and combining ability of 30 hybrids developed by crossing three females and ten male lines in line $\mathrm{x}$ tester fashion. Non-additive gene action played a major role in the inheritance of most of the traits (viz., days to 50 per cent flowering, days to maturity, plant height, number of primaries panicle ${ }^{-1}$, panicle weight, fodder yield plant $^{-1}$, grain yield plant $^{-1}$, leaf area index and harvest index) under study except panicle length, number of grains panicle $^{-1}$ and 100 seed weight for which additive gene action was found to be important. Based on consistent performance over four environments, AKMS-30A, AKR504, Rb-342-2 and AKR-354 were found to be best general combiners for grain yield and yield related traits. Among the hybrids, AKMS-30A X Rb-324-3, AKMS-70A X AKR-354, AKMS-70A X Rb- 342-2 and AKMS-30A X Rb-301-4-1 were found to be good specific combiners with highest standard heterosis and per se performance for grain yield plant ${ }^{-1}$ over the environments.

\section{Introduction}

In the field of plant breeding, the most important breakthrough has been considered as 'heterosis'. Exploitation of heterosis on commercial scale and the systematic varietal improvement through hybridization are the main tools to increase the sorghum production. The success in the development of superior hybrids and/or varieties depends on the choice of parents for hybridization and amount and type of genetic variability present in the base population to be improved. Verma and Kumar (1974) and Joshi (1979) emphasized that greater attention should be paid on the choice of parents for hybridization. This should be based not only on per se performance, as has been done generally, but also on adaptability, genetic diversity, and combining ability. Selection of parents for hybridization can be made with the help of combining ability analysis (Sprague and Tatum, 1942).

Besides its use in selection of parents, it indicates the nature and magnitude of various types of gene action involved in the expression of quantitative characters. Such information is of potential use in formulating and executing an efficient breeding programme for achieving maximum genetic gain with minimum resources and time. 
Therefore, the present investigation was undertaken to estimate magnitude of heterosis and to assess the combining ability of important yield contributing characters and to identify potential parents and crosses for further sorghum breeding programme.

\section{Materials and Methods}

The experiment was carried out across four environments (i.e. two locations and two seasons) during rabi 2012-13 and kharif 2013-14 at Dr. Panjabrao Deshmukh Krishi Vidyapeeth, Akola and Agricultural Research Station, Washim. The experimental material consisted of 43 entries, which included 13 parents and their resulting 30 hybrids (including checks viz., CSH-19R \& SPH1635). All these genotypes were grown in randomized block design with three replications. Each genotype was sown in two rows of $2.5 \mathrm{~m}$ length with inter row spacing of $45 \mathrm{~cm}$ and intra row spacing of $15 \mathrm{~cm}$. All the recommended practices were followed to raise good crop. The data were recorded for twelve characters (viz., days to 50 per cent flowering, days to maturity, plant height, number of primaries panicle ${ }^{-1}$, panicle length, panicle weight, number of grains panicle ${ }^{-1}$, 100 seed weight, fodder yield plant $^{-1}$, grain yield plant $^{-1}$, leaf area index and harvest index) from four environments and subjected to estimation of standard heterosis and combining ability analysis (Kempthorne, 1957).

\section{Results and Discussion}

From the resulted 30 hybrids, significant standard heterosis performance over both checks in desirable direction for grain yield and other yield components over test environments top four combinations (Table 1) viz., AKMS-30A X Rb-324-3, AKMS-70A X AKR-354, AKMS-70A $X$ Rb-342-2 and AKMS-30A X AKR-504 were identified in the present study.
Among 30 hybrids, the hybrid AKMS-30A X Rb-324-3 exhibited highest standard heterosis (38.00\% and $21.36 \%$ ) over both the checks (CSH-19R and SPH-1635) for grain yield. In addition, it showed significant heterosis for other traits like plant height, number of primaries panicle ${ }^{-1}$, panicle length, and panicle weight, number of grains panicle ${ }^{-1}$ and harvest index and found promising over tested environments.

On second position, hybrid AKMS-70A $\mathrm{X}$ AKR-354 recorded significant highest useful heterosis $(31.71 \%$ and $15.83 \%)$ over the checks (CSH-19R and SPH-1635) for grain yield; it also showed significant standard heterosis for fodder yield plant $^{-1}$, panicle weight and 100 seed weight over both the checks.

As far as heterotic performance for grain yield is concerned, hybrid AKMS-70A X Rb-342-2 ranked third and significant in desirable direction for other traits like number of primaries panicle $^{-1}$, panicle weight, 1000 seed weight and fodder yield plant $^{-1}$ over both kharif and rabi ckecks.

The cross AKMS-30A X AKR-504 ranked fourth and exhibited significant and positive standard heterosis over both the checks for grain yield plant $^{-1}$, days to $50 \%$ flowering, panicle length, panicle weight, number of grain panicle ${ }^{-1}$ and harvest index.

Grain yield is complex trait, depend on many attributes characters. Yield potential accompanied with desirable combination of traits has always been the major objective of sorghum breeding program (Kumar, 2013). Heterosis for end product i.e. yield is being manifested as the cumulative effect of heterosis for component traits. The elaborative study of above crosses revealed this fact as most of the crosses that exhibited positive and significant heterosis for yield also showed heterosis for most of the 
component characters viz., number of primaries panicle $^{-1}$, panicle length, panicle weight, number of grains panicle ${ }^{-1}, 100$ seed weight and harvest index. The findings of the present investigation are consistent with the earlier reports of Nandanwankar (1990) and Jain and Patel (2013).

The mean squares due to different sources of variation was estimated over the environments and presented as in pooled analysis of variance for combining ability (Table 2). Significant differences were found among the environments and among the crosses for the studied traits indicating sufficient variability among environments and crosses respectively. Mean squares due to males were significant for days to maturity, plant height, panicle length, number of grains panicle $^{-1}$ and 100 seed weight. Mean squares due to females were significant for panicle length, number of grains panicle ${ }^{-1}, 100$ seed weight and leaf area index. Significant male and female variance indicates substantial genetic variability for general combining ability among males and females respectively for concern traits. Mean squares due to males $\mathrm{x}$ female interaction were significant for all the characters under study which indicate genetic variability for specific combining ability among the crosses.

The variance due to environment $\mathrm{x}$ crosses interaction was found to be significant for all the characters except days to $50 \%$ flowering and days to maturity which indicates considerable amount of interaction between the crosses and environments. The environment $x$ male interaction observed significant for four characters only viz., number of primaries panicle ${ }^{-1}$, panicle weight, number of grains panicle ${ }^{-1}$ and harvest index, whereas significant environment $\mathrm{x}$ female interaction found for three characters only viz., panicle length, number of grains panicle ${ }^{1}$ and leaf area index. Significant environment $\mathrm{x}$ male and environment $\mathrm{x}$ female variance for these traits indicates considerable amount of interaction between environments and general combining ability among males and females respectively. Environments x males x females interaction was also found to be significant for the seven traits viz., plant height, panicle weight, number of grains panicle ${ }^{-1}, 100$ seed weight, grain yield plant $^{-1}$, leaf area index, harvest index which indicates susceptibility for specific combining ability among the crosses to the environments for these traits. Kenga et al., (2004) and Tadesse et al., (2008) also reported significant variation for genotype and genotype $\mathrm{x}$ environment interaction over the environments.

For most of the traits (viz., days to 50 per cent flowering, days to maturity, plant height, number of primaries panicle ${ }^{-1}$, panicle weight, fodder yield plant ${ }^{-1}$, grain yield plant ${ }^{-1}$, leaf area index and harvest index) the predictability ratio (GCA vs. SCA) over the environments found to be less than unity. This indicates importance of non-additive gene action in the inheritance of these traits and greater is predictability based on specific combining ability alone for improvement of respective trait. The same results were also reported by Kenga et al., (2004).

The predictability ratio GCA vs. SCA found to be more than unity over the environments for panicle length, number of grains panicle ${ }^{-1}$ and 100 seed weight indicating importance of additive gene action for inheritance of these traits and greater is the predictability based on general combining ability alone for improvement of respective trait. Additive gene action for panicle length and 100 seed weight was reported by Tadesse et al., (2008).

The general combining ability effects of promising parents based on consistent performance over four environments are presented in Table 3. 
Table.1 Potential hybrids based on significant standard heterosis in desirable direction for grain yield and other yield components

\begin{tabular}{|c|c|c|c|c|c|c|}
\hline \multirow[b]{2}{*}{$\begin{array}{l}\text { Sr. } \\
\text { No. }\end{array}$} & \multirow[b]{2}{*}{ Crosses } & \multirow[b]{2}{*}{$\begin{array}{l}\text { Mean performance for } \\
\text { grain yield (g / plant) }\end{array}$} & \multicolumn{2}{|c|}{ Standard heterosis for grain yield (\%) } & \multicolumn{2}{|c|}{ Significant Standard heterosis for other characters (\%) } \\
\hline & & & $\begin{array}{c}\text { CSH-19R } \\
\text { (Rabi check) }\end{array}$ & $\begin{array}{c}\text { SPH-1635 } \\
\text { (Kharif check) }\end{array}$ & $\begin{array}{c}\text { CSH-19R } \\
\text { (Rabi check) }\end{array}$ & $\begin{array}{c}\text { SPH-1635 } \\
\text { (Kharif check) }\end{array}$ \\
\hline 1 & AKMS- 30A X Rb-324-3 & 40.25 & $38.00 * *$ & $21.36 * *$ & $\begin{array}{l}4(16.04), 5(12.17), 6(40.20), \\
7(64.00), 12(72.82)\end{array}$ & $\begin{array}{l}3(32.66), 4(26.02), 5(6.23), \\
6(22.28), 8(20.23), 12(34.78)\end{array}$ \\
\hline 2 & AKMS- 70A X AKR-354 & 38.42 & $31.71 * *$ & $15.83 * *$ & $\begin{array}{l}\text { 6(32.22), 7(18.51), 8(12.95), } \\
9(9.66), 12(32.75)\end{array}$ & $\begin{array}{l}3(52.56), 6(15.32), 8(57.36) \\
9(10.16)\end{array}$ \\
\hline 3 & AKMS- 70A X Rb-342-2 & 38.33 & $31.43 * *$ & $15.58 * *$ & $\begin{array}{l}4(37.74), 6(31.35), 8(30.83), \\
9(20.98), 12(20.91)\end{array}$ & $\begin{array}{l}3(37.46), 4(49.59), 6(14.56), \\
8(82.27), 9(21.53)\end{array}$ \\
\hline 4 & AKMS-30A X AKR-504 & 37.25 & $27.71 * *$ & $12.37 * *$ & $\begin{array}{l}1(-8.70), 5(14.14), 6(29.32) \\
7(79.68), 12(66.55)\end{array}$ & $\begin{array}{l}1(-5.45), 2(-5.30), 3(28.79) \\
4(18.85), 5(8.10), \\
6(12.78), 7(12.07), 12(29.89)\end{array}$ \\
\hline
\end{tabular}

$*^{*}, *$ - significant at $5 \%$ and $1 \%$ level respectively

Parenthesis values represent standard heterosis values
1: Days to $50 \%$ flowering (days)
2: Days to maturity (days)
4: Number of primaries panicle
3: Plant height $(\mathrm{cm})$
7: Number of grains panicle ${ }^{-1}$
5: Panicle length $(\mathrm{cm})$
8: 100 seed weight $(\mathrm{g})$
6: Panicle weight $(\mathrm{g})$
9: Fodder yield plant ${ }^{-1}(\mathrm{~g})$
10: Grain yield plant $^{-1}(\mathrm{~g})$
11: Leaf area index
12: Harvest index (\%)

Table.2 Pooled analysis of variance for combining ability over four environments

\begin{tabular}{|c|c|c|c|c|c|c|c|c|c|c|c|c|c|}
\hline \multirow[b]{2}{*}{ Sources of variation } & \multirow[b]{2}{*}{ d.f. } & \multicolumn{12}{|c|}{ MSS } \\
\hline & & $\begin{array}{c}\text { Days to } \\
50 \% \\
\text { flowering }\end{array}$ & $\begin{array}{l}\text { Days to } \\
\text { maturity }\end{array}$ & $\begin{array}{l}\text { Plant } \\
\text { height }\end{array}$ & $\begin{array}{c}\text { No. of } \\
\text { primaries } \\
\text { panicle }^{-1}\end{array}$ & $\begin{array}{l}\text { Panicle } \\
\text { length }\end{array}$ & $\begin{array}{l}\text { Panicle } \\
\text { weight }\end{array}$ & $\begin{array}{l}\text { No. of grains } \\
\text { panicle }^{-1}\end{array}$ & $\begin{array}{c}100 \\
\text { seed } \\
\text { weight }\end{array}$ & $\begin{array}{l}\text { Fodder } \\
\text { yield } \\
\text { plant }^{-1}\end{array}$ & $\begin{array}{c}\text { Grain } \\
\text { yield } \\
\text { plant }^{-1}\end{array}$ & $\begin{array}{c}\text { Leaf } \\
\text { area } \\
\text { index } \\
(\text { LAI) } \\
\end{array}$ & $\begin{array}{c}\text { Harvesting } \\
\text { index } \\
\text { (HI) }\end{array}$ \\
\hline Environments & 3 & $604.88 * *$ & $69.29 *$ & $48811.03 * *$ & $1983.18^{* *}$ & $573.74 * *$ & $16074.39 * *$ & $4460110.89 * *$ & $7.56^{* *}$ & $19740.93 * *$ & $4872.66 * *$ & $3.00 * *$ & $2048.15^{* *}$ \\
\hline Crosses & 29 & $108.14 * *$ & $144.85 * *$ & $8974.15^{* *}$ & $557.07 * *$ & $36.47 * *$ & $750.28 * *$ & $1011628.00 * *$ & $3.88 * *$ & $3194.13 * *$ & $187.49 * *$ & $0.21 * *$ & $509.25 * *$ \\
\hline Females & 2 & 43.35 & 159.85 & 15129.16 & 965.33 & $234.05 * *$ & 2305.70 & $5902464.00 * *$ & $17.56 * *$ & 479.35 & 525.69 & $1.22 * *$ & 458.17 \\
\hline Males & 9 & 146.24 & $237.97 *$ & $16187.32 *$ & 860.53 & $36.87 *$ & 444.82 & $1412744.00 * *$ & $6.84 * *$ & 5575.57 & 118.79 & 0.08 & 735.08 \\
\hline Males x Females & 18 & $96.30 * *$ & $96.62 * *$ & $4683.68 * *$ & $359.98 * *$ & $14.32 * *$ & $730.19 * *$ & $267643.50 * *$ & $0.88 * *$ & $2305.06 * *$ & $184.27 * *$ & $0.17 * *$ & $402.02 * *$ \\
\hline Environments x Crosses & 87 & 21.84 & 21.42 & $2010.94 * *$ & $51.27 *$ & $6.17 * *$ & $276.15 * *$ & $97969.86^{* *}$ & $0.11 * *$ & $919.52 * *$ & $70.18^{* *}$ & $0.10 * *$ & $117.95 * *$ \\
\hline Environments x Females & 6 & 9.25 & 7.79 & 2037.43 & 29.35 & $16.23 * *$ & 169.90 & $211924.71 * *$ & 0.12 & 1739.56 & 40.30 & $0.19 *$ & 167.81 \\
\hline Environments x Males & 27 & 24.29 & 23.67 & 2081.51 & $79.84 *$ & 7.05 & $400.57 *$ & $134365.75^{*}$ & 0.09 & 1035.74 & 101.91 & 0.1 & $177.76 * *$ \\
\hline $\begin{array}{l}\text { Environments x Males x } \\
\text { Females }\end{array}$ & 54 & 22.01 & 21.81 & $1972.72 * *$ & 39.42 & 4.61 & $225.74 * *$ & $67110.27 * *$ & $0.11^{* *}$ & 770.29 & $57.63 * *$ & $0.08 * *$ & $82.51 * *$ \\
\hline Error & 232 & 17.65 & 18.7 & 241.14 & 36.48 & 3.85 & 77.78 & 21627.42 & 0.03 & 164.21 & 21.12 & 0.02 & 22.17 \\
\hline GCA Vs SCA & & 0.15 & 0.36 & 0.53 & 0.42 & 1.94 & 0.31 & 2.27 & 2.21 & 0.21 & 0.28 & 0.66 & 0.23 \\
\hline
\end{tabular}

*, **-significant at $5 \%$ and $1 \%$ level respectively 
Table.3 GCA effects of promising parents in desirable direction for yield and other traits over the environments

\begin{tabular}{|c|c|c|c|c|c|c|c|c|c|c|c|c|}
\hline \multirow[b]{2}{*}{ Genotypes } & \multicolumn{12}{|c|}{ GCA } \\
\hline & $\begin{array}{c}\text { Days to } \\
50 \% \\
\text { flowering }\end{array}$ & $\begin{array}{l}\text { Days to } \\
\text { maturity }\end{array}$ & $\begin{array}{l}\text { Plant } \\
\text { height }\end{array}$ & $\begin{array}{c}\text { No. of } \\
\text { primaries } \\
\text { panicle }^{-1}\end{array}$ & $\begin{array}{l}\text { Panicle } \\
\text { length }\end{array}$ & $\begin{array}{l}\text { Panicle } \\
\text { weight }\end{array}$ & $\begin{array}{c}\text { No. of } \\
\text { grains } \\
\text { panicle }^{-1}\end{array}$ & $\begin{array}{c}100 \\
\text { seed } \\
\text { weight }\end{array}$ & $\begin{array}{c}\text { Fodder } \\
\text { yield } \\
\text { plant }^{-1}\end{array}$ & $\begin{array}{c}\text { Grain } \\
\text { yield } \\
\text { plant }^{-1}\end{array}$ & $\begin{array}{c}\text { Leaf } \\
\text { area } \\
\text { index } \\
\text { (LAI) }\end{array}$ & $\begin{array}{c}\text { Harvesting } \\
\text { index } \\
\text { (HI) }\end{array}$ \\
\hline \multicolumn{13}{|l|}{ Females } \\
\hline AKMS- 30A & - & - & - & - & $1.42 * *$ & $3.67 * *$ & $255.81 * *$ & - & - & $1.71 * *$ & $0.07 * *$ & $1.71 * *$ \\
\hline \multicolumn{13}{|l|}{ Males } \\
\hline AKR- 504 & - & - & - & $5.10 * *$ & $2.20 * *$ & $4.60 * *$ & $282.92 * *$ & - & - & $2.32 * *$ & - & $3.80 * *$ \\
\hline AKR-354 & - & - & $31.79 * *$ & - & - & $3.46^{*}$ & - & - & $9.56^{* *}$ & $1.73^{*}$ & $0.07 * *$ & - \\
\hline
\end{tabular}

$*, * *$ - significant at $5 \%$ and $1 \%$ level respectively

Table.4 Mean yield performance, standard heterosis and SCA effects of the promising crosses over the environments

\begin{tabular}{|c|c|c|c|c|c|c|c|}
\hline \multirow{2}{*}{$\mathbf{S N}$} & \multirow{2}{*}{ Crosses } & \multirow{2}{*}{$\begin{array}{c}\text { Grain } \\
\text { yield } \\
\text { plant }^{-1}(\mathrm{~g})\end{array}$} & \multicolumn{2}{|c|}{$\begin{array}{c}\text { Standard heterosis }(\%) \\
\text { over }\end{array}$} & \multirow{2}{*}{$\begin{array}{l}\text { SCA effects for } \\
\text { Grain yield plant } \\
{ }_{1}^{-}\end{array}$} & \multirow{2}{*}{$\begin{array}{l}\text { GCA effects of } \\
\text { parents for } \\
\text { grain yield }\end{array}$} & \multirow{2}{*}{$\begin{array}{l}\text { Significance SCA } \\
\text { effects for other } \\
\text { characters in } \\
\text { desirable direction }\end{array}$} \\
\hline & & & CSH-19R & SPH-1635 & & & \\
\hline 1 & $\begin{array}{l}\text { AKMS- 30A X Rb- } \\
324-3\end{array}$ & 40.25 & $38.00 * *$ & $21.36 * *$ & $5.98 * *$ & $1.71 * * \times 0.82$ & $4,5,6,7,12$ \\
\hline 2 & $\begin{array}{l}\text { AKMS- 70A X AKR- } \\
354\end{array}$ & 38.42 & $31.71 * *$ & $15.83^{*}$ & $4.33 * *$ & $0.61 \times 1.73^{* *}$ & $6,7,11$ \\
\hline 3 & $\begin{array}{l}\text { AKMS- 70A X Rb- } \\
342-2\end{array}$ & 38.33 & $31.43 * *$ & $15.58 * *$ & $3.75^{* *}$ & $0.61 \times 2.23^{* *}$ & $4,6,8,9,11$ \\
\hline 4 & $\begin{array}{l}\text { AKMS- 30A X Rb- } \\
\text { 301-4-1 }\end{array}$ & 33.42 & $14.57 *$ & $0.75^{\mathrm{NS}}$ & $3.45 *$ & $1.71 * * \mathrm{X}-3.49 *$ & $3,6,8,11,12$ \\
\hline
\end{tabular}

*,**- significant at $5 \%$ and $1 \%$ level respectively
1: Days to $50 \%$ flowering (days)
2: Days to maturity (days)
4: Number of primaries panicle
5: Panicle length $(\mathrm{cm})$
7: Number of grains panicle
8: 100 seed weight $(\mathrm{g})$
3: Plant height $(\mathrm{cm})$
10: Grain yield plant $^{-1}(\mathrm{~g})$
11: Leaf area index
6: Panicle weight $(\mathrm{g})$
9: Fodder yield plant ${ }^{-1}(\mathrm{~g})$
12: Harvest index (\%) 
Among female parents, AKMS-30A exhibited significant gca effects over the environments for grain yield plant $^{-1}$, panicle length, panicle weight, number of grains panicle ${ }^{-1}$, leaf area index and harvest index.

Among male parents, AKR-504, Rb-342-2 and AKR-354 exhibited significantly high gca effects for yield and yield related traits. AKR504 showed significant and desirable gca effects for grain yield plant $^{-1}$, number of primaries panicle $^{-1}$, panicle length, panicle weight, number of grains panicle ${ }^{-1}$ and harvest index.

Similarly, Rb-342-2 exhibited significant and desirable gca effects for grain yield plant $^{-1}$ and fodder yield plant ${ }^{-1}$ with other important traits viz., plant height, number of primaries panicle $^{-1}$, panicle weight and 100 seed weight.

Further, the male parent AKR-354 showed significant gca effects in desirable direction for grain yield plant ${ }^{-1}$, fodder yield plant $^{-1}$ plant height, number of primaries panicle ${ }^{-1}$, panicle weight and leaf area index.

Thus above promising male and female parents having high gca effects for yield and yield related traits (more commonly viz., panicle length, panicle weight, number of primaries panicle $^{-1}$, number of grainspanicle ${ }^{-1}$, leaf area index and harvest index) can be suitably used in the hybridization programmes over the environments under study for improvement of individual trait per se. Similar types of results and prediction have been reported by Borikar et al., (2000), Kenga et al., (2004) and Kale (2011). The specific combining ability effect is indicative of heterosis and also non additive gene action.

The promising hybrids over the environments with respect to specific combining ability effects for grain yield and other component traits are presented in Table 4 along with their mean grain yield and standard heterosis values. Based on high mean performance, significantly high sca effect, and significant heterosis over standard check/s four promising hybrids (viz., AKMS-30A X Rb324-3, AKMS-70A X AKR-354, AKMS-70A $\mathrm{X} \mathrm{Rb}-342-2$ and AKMS-30A X Rb-301-4-1) were selected for grain yield over the test environments.

AKMS-30A X Rb-324-3 exhibited significant sca effects for number of primaries panicle ${ }^{-1}$, panicle length, panicle weight, number of grains panicle ${ }^{-1}$, grain yield plant ${ }^{-1}$ and harvest index.

AKMS-70A X AKR-354 showed significant sca effects for grain yield with other three traits viz., panicle weight, number of grains panicle $^{-1}$ and leaf area index.

Hybrid, AKMS-70A X Rb-342-2 recorded high sca effects for number of primaries panicle $^{-1}$, panicle weight, 1000 seed weight, fodder yield plant ${ }^{-1}$ and leaf area index.

In addition, the hybrid AKMS-30A X Rb-3014-1 exhibited significant sca effect for grain yield and other important traits viz., plant height, panicle weight, 1000 seed weight, leaf area index and harvest index.

All the four hybrids also recorded significantly desirable standard heterosis over checks for grain yield plant ${ }^{-1}$. Out of these, four hybrids, AKMS-30A X Rb-301-4-1 was combination of high $\mathrm{x}$ high gca effect. The hybrid AKMS-30A X Rb-324-3 was combination of high $\mathrm{x}$ low gca effect whereas, hybrid AKMS-70A X AKR-354 and AKMS70A X Rb-342-2 recorded low $x$ high gca combination for grain yield (Table 4). Thus, it could be concluded that, hybrids showing high sca effects for grain yield and other important traits were having at least one parent with high gca effect. The performance of cross combination is therefore largely in agreement with the gca effects of parents 
involved in the combinations. Chaudhary and Narkhede (2004) and Kale (2011), also recorded similar conclusion.

Thus, out of thirty hybrids, above mentioned four hybrids are expected to be promising over environments under study and which can be exploited for heterosis breeding programme. Promising hybrids over environments also identified by Borikar et al., (2000) and Kenga et al., (2004).

The present study has helped in selecting good combiners over environments for grain yield and other yield contributing characters. The parents, AKR-504, Rb-342-2 and AKR354 showed good general combining ability over environments for grain yield along with other important yield contributing characters. These parents can be further utilized in sorghum hybrid development programme for exploitation of their good general combining ability. Similarly, the hybrids AKMS-70A X AKR-354, AKMS-70A X Rb-342-2 and AKMS-30A X Rb-301-4-1 showed desirable standard heterosis percentage along with good sca effects for grain yield and other important yield contributing characters over environments. So these hybrids can be commercially exploited over different environments using heterosis breeding after its thorough evaluation in multilocation trials.

\section{References}

Borikar, S. T., Jahagirdar J. E. and Ambekar S. S. 2000. Adoption inrelatioln to seasons in sorghum, Vasantrao Naik Memorial National Agril. Seminar, 8: 18-19.

Chaudhary, S. B., and Narkhede B. N. 2004. Line $\mathrm{x}$ Tester analysis in rabi sorghum hybrids. $\mathrm{J}$.
Soils Crops. 14(1): 209-210.

Jain, S. K., and Patel P. R. 2013. Heterosis studies for yield and its attributing traits in Sorghum [Sorghum bicolor (1.) Moench]. Forage Res., 39(3): 114-117.

Joshi, A. B., 1979. Breeding methodology for autogamous crops. Indian J. Genet., 39(3): 567-578.

Kale, P. B., 2011. Studies on combining ability of newly developed sorghum lines. M. Sc. (Agri.) Thesis. Dr. PDKV, Akola.

Kempthorne, O., 1957. An Introduction to Genetic Statistics, New York, John Wiley and Sons, 1st Edn, pp. 456-471.

Kenga, R., and Alabi S. O. and Gupta S. C. 2004. Combining ability studies in tropical sorghum (Sorghum bicolor (L.) Moench). Field Crops Research, 88(2-3): 251-260.

Kumar B. A., 2013. Studies on genetic parameters and inter-relationships among yield and yield contributing traits in sorghum (Sorghum bicolor L. Moench). The Bioscan. 8(4): 1311-1314.

Nandanwankar, K. G., 1990 Heterosis studies for grain yield characters in rabi sorghum [Sorghum bicolor (L.) Moench]. Indian J. of Genet.Pl. Br., 50: 83-85.

Sprague, G. F., and Tatum L. A. 1942. General vs. specific combining ability in single crosses of corn. J. Amer. Soc. Agron., 34: 923-932.

Tadesse, T., Tesso T. and Ejeta G. 2008. Combining ability of introduced sorghum parental lines for major morpho-agronomic traits. An Open Access Journal published by ICRISAT (ejournal.icrisat.org). 6:1-7.

Verma, M. M., and Kumar J. 1974. Breeding for yield in self-pollinators an introspection and reorientation. Crop Improv. 1(1 and 2): 1531.

\section{How to cite this article:}

Jadhav, R.R. and Deshmukh, D.T. 2017. Heterosis and Combining Ability Studies in Sorghum (Sorghum bicolor (L.) Moench) Over the Environments. Int.J.Curr.Microbiol.App.Sci. 6(10): 3058-3064. doi: https://doi.org/10.20546/ijcmas.2017.610.360 